\title{
INTERNATIONAL CRYPTOCURRENCY MARKET AND DISTINGUISHING FEATURES OF ITS DEVELOPMENT
}

\section{Ushakov \\ Denis \\ Sergeevich}

\section{Podolskaya \\ Tatiana \\ Valentinovna}

\section{Tomashevskaya \\ Ludmila \\ Avramovna}

Sysoeva
Anna
Andreevna

Doctor of Economic Sciences, Professor, Suan Sunandha Rajabhat University (1UThong Nok Road, Dusit, Bangkok, 10300, Thailand), Professor of Department of International Economic Relations; South-Russian Institute of Management - branch of Russian Presidential Academy of National Economy and Public Administration (70/54, Pushkinskaya St., Rostov-on-Don, 344002, Russian Federation). Author of 33 publications indexed in IDB Scopus with hi-5 in Scopus. E-mail: fintaliano@yandex.ru Candidate of Economic Sciences, Associate Professor, Head of Department of International Economic Relations; South-Russian Institute of Management - branch of Russian Presidential Academy of National Economy and Public Administration (70/54, Pushkinskaya St., Rostov-on-Don, 344002, Russian Federation). E-mail: podolskayat@uriu.ranepa.ru

Candidate of Economic Sciences, Associate Professor, Associate Professor of Department of Foreign languages and speech communications; South-Russian Institute of Management - branch of Russian Presidential Academy of National Economy and Public Administration(70/54, Pushkinskaya St., Rostov-on-Don, 344002, Russian Federation). E-mail: inyaz@ uriu.ranepa.ru

Master of Department of International Economic Relations; South-Russian Institute of Management - branch of Russian Presidential Academy of National Economy and Public Administration (70/54, Pushkinskaya St., Rostov-on-Don, 344002, Russian Federation).E-mail: anna_sysoeva94@mail.ru

\section{Abstract}

The article analyzes the emergence and development of cryptocurrency market, gives an overview of different approaches to defining cryptocurrency. It gives an outline of its key participants, their particular functions and factors which have an impact on its current trends.

Keywords: cryptocurrency, blockchain, Bitcoin, cryptocurrency market, electronic money, financial transactions, finance, capitalization, financial market.

The blockchain technology development has carved the path for cryptocurrencies. Cryptocurrencies emerged at the center of a complex intersection of economics, cryptography and ideology.

The first virtual currency - Bitcoin - gained widespread recognition and revolutionized the world of finance. Cryptocurrencies have become a generally accepted phenomenon after pseudonymous developer Satoshi Nakamoto designed and created an innovative decentralized 'peer-to-peer' (P2P) payment network with no middlemen (such as governments or banks) and no or minimal transaction costs, according to Coase's theorem.

Bitcoin is an example of how an egalitarian, decentralized organization is able to handle the issues which are beyond the capabilities of traditional financial institutions. Like the Internet, Bitcoin is the property of the entirety of the Bitcoin community. It has no governing or controlling body. It provides incredible opportunities for making financial transactions more efficient and, most notably, more transparent.

The rise of Bitcoin made blockchain, its underlying technology, increasingly popular. A group of pseudonymous developers, the so called cyberpunks, is believed to lay the ground for the cryptocurrency in 1991. The developers were engaged in cryptography and concerned about safeguarding anonymity in the calculations.

In 1993, an American mathematician and programmer Eric Hughes was one of the first to come up with the concept of multistage encryption of payment transactions in order to guarantee their confidentiality and security. At the same time, Timothy May, an electronic engineer and computer scientist at Intel, published a paper on safeguarding the security of payment transactions through encryption, and making transactions without the need for intermediaries. To implement such ideas, it was necessary to create a new settlement mechanism, with no banking sector involved.

In 1998, Wei Dai described the concept of digital b-money, which enabled anonymous interacting parties to enforce contracts among themselves. It was only in 2008 when Satoshi Nakomoto designed and introduced Bitcoin.

The World Bank defines cryptocurrencies as a digital representation of value, which is denominated in their own unit of account, distinct from electronic money, which is simply a digital payment mechanism, represented and denominated in fiat (fiduciary) money [1]. In its 2012 report, the European Central Bank (ECB) classified cryptocurrencies as a subset of virtual currencies; a form of unregulated digital money, usually issued and controlled by their developers and used and accepted among the members of a specific virtual community [2].

In a new report, the ECB defines virtual currency as a digital representation of value not issued by the central bank, credit institution or issuer of electronic money, which in some circumstances can be used as an alternative to money [3]. Cryptocurrencies such as Bitcoin are a decentralized bi-directional (bilateral) virtual currency.

The International Monetary Fund (IMF) classifies virtual currencies as a digital representation of value issued by private developers and denominated in their own unit of account [4]. In line with this view on virtual currency, its scheme includes two elements: 
1. The digital expression of value, which can be transferred to the other party.

2. The existence of basic payment and settlement mechanisms, including a publicly distributed ledger system.

The Bank for International Settlements identifies three aspects of cryptocurrencies, which, based on their view, have some monetary characteristics, e.g. they can be used as a medium of exchange. They are not guaranteed by a central bank or public authority, their value is determined by their acceptance as a medium of exchange. Cryptocurrencies are usually exchanged through decentralized, distributed ledgers, which secure P2Pexchange. They are designed and used by non-banking institutions [5].

The FATF (Financial Action Task Force) classifies cryptocurrencies as a subset of virtual currencies, which it defines as a digital representation of value that can be digitally traded and function as a medium of exchange; and/or a unit of account and/or a store of value, but do not have legal tender status in any jurisdiction. This currency performs the above-mentioned functions only by agreement and within the virtual currency user community [6].

Cryptocurrencies are essentially a decentralized payment network of peer users, which is maintained by the users themselves, with no central authorities or intermediaries [7].

'Cryptocurrencies' got their name due to the use of cryptography in decentralized virtual currency systems.

The key features exhibited by cryptocurrencies, according to Marco Streng, are: duration, divisibility, accessibility, globality, anonymity, open source, peer-to-peer, deflatory and decentralized nature [8]. Each unit of cryptocurrency is generated due to the computing power that users use, through a certain complex algorithm.

To understand how the cryptocurrency market works, we will hereafter have a look at its key participants and their particular roles.

A first, and very important, player is the 'cryptocurrency user'. This is a natural person or legal entity who obtains coins to use them to purchase real or virtual goods or services, to make P2P payments, or to hold them for investment purposes (in a speculative manner).

A second player is the 'miner', who participates in validating transactions on the blockchain by solving a 'cryptographic puzzle'. The process of mining relates to cryptocurrencies that are based on a PoW consensus mechanism. A miner supports the network, by harnessing computing power to validate transactions, and is rewarded with newly mined coins (i.e., through an automatic decentralized new issuance) [9].

A third group of key participants are the so called 'cryptocurrency exchanges'. They are online platforms where you can buy, sell or exchange cryptocurrency for the digital currencies or traditional national currency, as well as make more money through the difference in exchange rate. They usually function both as a bourse and as a form of exchange office. Examples of well-known cryptocurrencies exchanges are: Bitfinex and Coinbase (both operate both as regular cryptocurrency exchanges and as wallet providers), Binance, HitBTC, Poloniex, and GDAX.

Some exchanges are pure cryptocurrency exchanges, which means that they only accept payments in other cryptocurrencies, usually Bitcoin (e.g. Binance), while others also accept payments in fiat currencies such as the US dollar or euro (e.g. Coinbase). Furthermore, many cryptocurrency exchanges only allow their users to buy a particular selection of coins.

In general, cryptocurrency exchanges offer their users a wide array of payment options, such as wire transfers, PayPal transfers, credit cards and other tokens [10]. Some cryptocurrency exchanges also provide statistics on the cryptocurrency market (like trading volumes and volatility of the coins traded) and offer conversion services to merchants who accept payments in cryptocurrencies.

A fourth group of key participants are 'trading platforms'. They also play an important role in the exchange of cryptocurrencies (and, most notably, allow cryptocurrency users to buy coins with cash). Trading platforms are market places that bring together different cryptocurrency users that are either looking to buy or sell coins, providing them with a platform on which they can directly trade with each other.

Trading platforms are sometimes referred to as 'P2P exchanges' or 'decentralized exchanges' [11]. They differ from cryptocurrency exchanges in a number of ways. Trading platforms simply connect the buyer with the seller, allowing them to conduct a deal online or even locally in-person. A well-known example of a trading platform for Bitcoins is LocalBitcoins.

A fifth group of key players are the so-called 'wallet providers'. Wallet providers are those entities that provide cryptocurrency users with digital wallets or e-wallets, which are used for holding, storing and transferring coins. Simply put, a wallet holds a cryptocurrency user's cryptographic keys. A wallet provider typically translates a cryptocurrency user's transaction history into an easily readable format which looks like a regular bank account [12].

A final group of key players to be distinguished are the so called 'coin offerors'. Coin offerors are individuals or legal entities that offer coins to cryptocurrency users upon the coin's initial release, either against payment (i.e., through a crowd sale), or at no charge (e.g., Stellar), normally to fund the coin's further development or boost its initial popularity. The coins these coin offerors offer to cryptocurrency users are created or 'pre-mined' prior to the coin's official release.

In recent years, the number of cryptocurrencies has grown significantly. Currently, there are several hundred cryptocurrencies in circulation with a total market capitalization of over 110 billion dollars.

Altcoins are all coins that are an alternative to Bitcoin. There are two types of Altcoins:

1. Altcoins that are built using Bitcoin's original open source protocol, with a number of changes to its underlying codes. An example of such an altcoin is Litecoin [13].

2. Altcoins that are not based on the Bitcoin' open source protocol, but that have their own protocol and distributed ledger. Well-known examples of such altcoins are Ethereum and Ripple [14]. 
3. The cryptocurrencies that have the highest market capitalization include: Bitcoin, Ethereum, XRP and others. Table 1 presents data on the market capitalization of the cryptocurrency market.

Table 1

The market capitalization cryptocurrency online at 2019/2020 year [15]

\begin{tabular}{|c|c|c|}
\hline Title & Capitalization & Price \\
\hline \multicolumn{3}{|c|}{$\begin{array}{l}\text { Total capitalization 2017: } \mathbf{\$} \mathbf{5 7 0} \text { billion (December 31, 2017) } \\
\text { Total capitalization 2018: } \mathbf{1 4 0} \text { billion (December 31, 2018) } \\
\text { Total capitalization 2019: } \mathbf{2 2 6 . 8} \text { billion }\end{array}$} \\
\hline $\begin{array}{l}\text { 1. Bitcoin (BTC)Coins: } \\
18004975 \text { BTC }\end{array}$ & $\begin{array}{l}\text { \$147.99 billion. } \\
\text { Share: } 65.25 \%\end{array}$ & $\begin{array}{l}\mathbf{\$ 8 , 2 1 9}(\uparrow 1.44 \%) \\
1.0 \text { btc }\end{array}$ \\
\hline $\begin{array}{l}\text { 2. Ethereum (ETH) } \\
\text { Coins: } 108,238,828 \mathrm{ETH}\end{array}$ & $\begin{array}{l}\text { \$ } 18.86 \text { billion. } \\
\text { Share: } 8.32 \%\end{array}$ & $\begin{array}{l}\$ 174.3(\downarrow-0.3 \%) \\
0.02120792 \text { btc }\end{array}$ \\
\hline $\begin{array}{l}\text { 3. XRP (XRP) } \\
\text { Coins: } 43242653330 \text { XRP }\end{array}$ & $\begin{array}{l}\text { \$12.65 billion. } \\
\text { Share: } 5.58 \%\end{array}$ & $\begin{array}{l}\$ 0.29242(\downarrow-0.24 \%) \\
0.00003558 \text { btc }\end{array}$ \\
\hline $\begin{array}{l}\text { 4. Bitcoin Cash }(\mathbf{B C H}) \\
\text { Coins : } 18069638 \mathrm{BCH}\end{array}$ & $\begin{array}{l}\text { \$4.19 billion. } \\
\text { Share: } \mathbf{1 . 8 5 \%}\end{array}$ & $\begin{array}{l}\$ 231.7(\uparrow 3.64 \%) \\
0.02819547 \text { btc }\end{array}$ \\
\hline $\begin{array}{l}\text { 5. Tether (USDT) } \\
\text { Coins: } 4,108,044,456 \text { USDT }\end{array}$ & $\begin{array}{l}\$ 4.13 \text { billion. } \\
\text { Share: } \mathbf{1 . 8 2 \%}\end{array}$ & $\begin{array}{l}\text { \$1.004 ( } \uparrow 0.17 \%) \\
0.00012222 \text { btc }\end{array}$ \\
\hline
\end{tabular}

Cryptocurrencies exhibit a wide range of different features. Some of them are based on Bitcoin's original open source protocol, while others constitute an entirely new platform and/or ecosystem. Some utilize a PoW mechanism, others employ another form of consensus mechanism. Most are characterized as pseudo-anonymous, yet some are fully anonymous (meaning that the amount of coins their users own, send and receive is not observable, traceable or linkable through the blockchain's transaction history) [16].

Considerable public interest in cryptocurrencies calls for comprehensive analysis of factors which keep up or affect their popularity and understanding how cryptocurrencies can be built into the economy.

Initially, in 2009, one Bitcoin cost a few cents, and only in February 2011 did its value rise to one dollar. The emergence of cryptocurrency exchanges, recognition of the potential and possibilities to use cryptocurrencies increased their value.

Bitcoin has no internal liquidity value: it does not give the right to future cash flows, it is not a promissory note, there is no guarantee of its use as payment for goods and services. Bitcoin's price is completely determined by the consumers' desire to buy it and the owners' desire (early miners' and investors') to fix the profit. A cryptocurrency's value is made up of its ability to perform a transaction (payment) function and a function of generating income (for investors) [17].

The first tangible cryptocurrency market correction took place in 2013-2014 - it is believed to start on December 5, 2013 - the highest point of the current cryptocurrency market since its inception. Capitalization at that time amounted to $\$ 15.6$ billion, and the bitcoin exchange rate was $\$ 1125$. It was from this point that the market began to decline. The correction was completed in early 2015 , with the price of bitcoin dropping to $\$ 175$, and the total capitalization amounting to only $\$ 3$ billion. After this minimum, a long-term upward movement began.

In the period of correction described, the market fell by $80 \%$, and Bitcoin decreased by $85 \%$. The internal trends of the market, its overheating and China's intention to ban banks and other financial institutions from accepting cryptocurrency as a medium of exchange resulted in a deep recession. As panic was spreading across the market, the already significant drop only increased. The market growth and fall during that period were greatly influenced by the cryptocurrency market-related news in general.

In 2017, the cryptocurrency market showed strong growth, Bitcoin being the main driver. Early in the year, the value of this cryptocurrency amounted to $\$ 1,000$, and the capitalization was $\$ 17.6$ billion. Late in May, it grew to $\$ 2,000$, and afterwards, with small pullbacks, the price was increasing steadily until it broke the psychological barrier of 10 thousand dollars in November and, finally, 20 thousand dollars in December, with capitalization of $\$ 592$ billion.

In 2017, within a year, the market had grown by about 33 times, due to several reasons: the rapid infrastructure development, the increasing interest of institutional and individual investors in cryptocurrencies, the legalization of bitcoin in Japan and other favourable factors.

However, the fascination with cryptocurrencies raised concern at the political level: South Korea announced restrictions on cryptocurrencies, China expressed its desire to ban mining, and India voiced the idea of banning cryptocurrencies. These developments, combined with the newcomers' panic, caused by the declining cryptocurrencies market, brought about the repetition of the 2014 scenario and the market fell even more.

Throughout 2017, the cryptocurrency market showed significant growth, after which most cryptocurrencies underwent correction in early 2018. In January and early February, the price of most popular coins and tokens 
fell to the figure of early December, in line with many experts' predictions. A signal to market participants was a change in the Bitcoin's price. In many cases, when the price fell to 30-45\% following steep rises, the cost of the remaining altcoins was also subject to adjustment. In February 2018, the cryptocurrency market capitalization fell by another $15 \%$ (from $\$ 517$ billion to $\$ 440$ billion), the negative trend continued in March.

The reason for such market changes was a series of events. In early January 2018, the cryptocurrency market capitalization reached a record figure of $\$ 700$ billion, then it increased to $\$ 830$ billion, which brought about the growth in the entire market. However, a series of unfavourable events triggered a market decline: Indian banks blocked accounts of Indian cryptocurrency exchanges; the Japanese Cryptocurrency Exchange Coincheck was hacked and about $\$ 500$ million were stolen; Facebook banned cryptocurrency ads; and China blocked access to all foreign cryptocurrency exchanges [18].

The Bitcoin exchange rate for the first quarter of 2018 fell by $50 \%$. Its decline was lower than the market dipped, which was due to its lower volatility compared to altcoins. The extensive use of new technologies by large players reduced the commission on transfer within the Bitcoin network which also contributed to the fall.

Ripple's capitalization in the first quarter decreased by over $70 \%$, as a result of the overvaluation in late 2017, which was caused by speculative demand.

In the second quarter, the cryptocurrency market capitalization fell another $2.3 \%$ to $\$ 257.7$ billion. In April, there was a growth of $60.4 \%$, in May and June the market dipped by $21.7 \%$ and $22.2 \%$, respectively [19].

Let us have a look at the key events that influenced the cryptocurrency exchange rate in the second quarter of 2018. In April, the market reacted with growth to a series of positive developments: the first delivery of gasoline from China to Singapore was made, completely built on blockchain technology; the FRS announced it does not consider cryptocurrencies a threat to the US financial system; a \$1.6 billion blockchain investment fund was introduced in China. However, in May-June the positive attitude of the market players turned negative, which affected the market decline: Japan tightened the rules for cryptocurrency exchanges to prevent large-scale attacks on them (e.g. January attack on Coincheck); Korea announced stricter requirements for financial institutions and the regulation of cryptocurrency exchanges as commercial banks; Bitcoin's price fell to $\$ 6,000$, updating the minimum of 2018.

The April events mostly had a positive impact on the cryptocurrency market, which led to its growth from $\$ 263.9$ to $\$ 423.2$ billion, i.e. by $\$ 160$ billion. May and June, in turn, saw a drop in the cryptocurrency market by approximately $\$ 165$ billion. In the third quarter, capitalization decreased by $13.3 \%$ from $\$ 257.7$ billion to $\$ 223.3$ billion.

Thus, the cryptocurrency market exhibits a rather high volatility - with long periods of strong growth, followed by correction stages of a year or more. Such a period offers good opportunity for those wishing to enter the market on favorable terms. The cryptocurrency market is susceptible to the developments regarding its regulation, hacking of exchanges and wallets, support or prohibition by governments, recognition by major corporations, institutional and reputable private investors - politicians, technology experts. Skepticism regarding cryptocurrencies gave way to fascination, which was triggered by advances in blockchain technology and greatest opportunities for decentralization. While market capitalization was rapidly growing in 2017, many experts presumed that cryptocurrency market exhibited some pyramid features at its core, but gradually such rhetoric has been changing. Financial institutions introduced bitcoin futures, the cryptocurrency market has become attractive to major investors.

To conclude it all, the analysis of various definitions set out above does not allow to identify a generally accepted definition of the term 'cryptocurrency' available in the regulatory space. Furthermore, there is a certain conceptual confusion in distinguishing between virtual, digital money and cryptocurrency. Yet, the differences between cryptocurrencies and virtual money are significant and fundamental. The generation of new cryptocurrency units is usually determined by a computer protocol. No organization can control and regulate the issuance of cryptocurrency, this process is determined by the algorithm embedded in the scheme. Bitcoin, as the first and most popular cryptocurrency, is a network that allows users to exchange rights to the digital asset of the same name. First, the system exchanges digital assets between two participants without an intermediary, then the operation is registered by the network nodes in a decentralized public distributed database, which is the blockchain. The emergence of cryptocurrencies is the only precedent in the world of exchange systems. The introduction of distributed ledger technology and cryptographic protocol made it possible to transfer money as information in payment systems operating on a decentralized basis, that is, without the need for either a third party or a government.

\section{References}

1. World Bank Group Distributed Ledger Technology (DLT) and blockchain, 2017, FinTech note, no. Washington 1., D. The C. - [Electronic resource]. Access mode -

http://documents.worldbank.org/curated/en/177911513714062215/pdf/122140-WP-PUBLIC-DistributedLedger-Technology-and-Blockchain-Fintech-Notes. pdf, IV. (Date of access - 29.06.2019).

2. ECB Virtual Currency Schemes, October 2012. - [Electronic resource]. Access mode https://www.ecb.europa.eu/pub/pdf/other/virtualcurrencyschemes201210en.pdf,13. (Date of access 29.06.2019).

3. ECB Virtual Currency Schemes - a further analysis, February 2015. - [Electronic resource]. Access mode https://www.ecb.europa.eu/pub/pdf/other/virtualcurrencyschemesen.pdf.4. (Date of access - 29.06.2019).

4. IMF Staff Discussion Note Virtual Currencies and Beyond: Initial Considerations, January 2016. - [Electronic resource]. Access mode - https://www.imf.org/external/thepubs/ft/sdn/2016/sdn1603.pdf.7. (Date of access - 29.06.2019). 
5. Sberbank CIB. Russian financials. Who innovates wins: Lifting the lift of Fintech in Russia // October, 2016. [Electronic resource]. Access mode -

http://www.vostokemergingfinance.com/content/uploads/2017/05/Sberbank-Russian-Fintech.pdf (Date of access 30.06.2019).

6. FATF, "Virtual Currencies - Key Definitions and Potential AML / CFT Risks", June 2014. - [Electronic resource]. Access mode - http://www.fatf-gafi.org/media/fatf/documents/reports/Virtual-currency-key-definitionsand-potential-aml--cft-risks.pdf.4. (Date of access - 30.06.2019).

7. Leiba A. Real life of virtual money // ES-LAWYER. - 2014. - No. 23. - S. 45.

8. Streng M. Blockchain \& Opportunities in Cryptocurrencies Mining // Blockchain \& Bitcoin Conference Russia // 2017, April 19. - [Electronic resource]. Access mode -

https://www.forbes.com/sites/julianmitchell/2018/06/20/hive-the-blockchain-mining-company-providing-thebackbone-for-cryptocurrency/\#77e5886e5a34 (Date of access - 30.06.2019).

9. FATF, "Virtual Currencies - Key Definitions and Potential AML / CFT Risks", June 2014. - [Electronic resource]. Access mode - http://www.fatf-gafi.org/media/fatf/documents/reports/virtual-currency-key-definitionsand-potential-aml-cft-risks. pdf.7. (Date of access - 31.07.2019).

10. ECB Virtual Currency Schemes - a further analysis, February 2015. - [Electronic resource]. Access mode https://www.ecb.europa.eu/pub/pdf/other/virtualcurrencyschemesen.pdf.8. (Date of access - 02.07.2019).

11. Marshall A. P 2 P Cryptocurrency Exchanges, Explained, April 2017. - [Electronic resource]. The access mode is https://cointelegraph.com/explained/p2p-cryptocurrency-exchanges-explained.

12. Tapscott D. Blockchain technology: what drives financial revolutions today /D. Tapscott. - M.: Eksmo, 2017. P. 226.

13. J. Martindale "What is Litecoin? Here's everything you need to know", January 2018. - [Electronic resource]. Access mode - https://www.digitaltrends.com/computing/what-is-litecoin/. See also: T. MANDJEE, "Bitcoin, its Legal Classification and its Regulatory Framework", 15 J. Bus. \& Sec. Of L. 157, 2016, http://digitalcommons.law.msu.edu/jbsl.

14. A. Zainuddin, "Coins, Tokens \& Altcoins: What's the Difference?", 2017. - [Electronic resource]. The access mode is https://masterthecrypto.com/differences-between-cryptocurrency-coins-and-tokens/.

15. Market capitalization of cryptocurrencies online // URL:https://zarabotat-na-sajte.ru/bitcoin/kapitalizaciyakriptovalyut.html (Date of access - 25.10.2019).

16. A. Zainuddin, "Guide on Privacy Coins: Comparison of Anonymous Cryptocurrencies", 2017. - [Electronic resource]. The access mode is https://masterthecrypto.com/privacy-coins-anonymous-cryptocurrencies/

17. Cryptocurrencies: a new financial system of the 21st century? ACI Financial Association. - [Electronic resource]. The access mode is https://news.nes.ru/files/NEWS/ACI-Crypto.pdf (Date of access - 20.10.2019).

18. Overview of key developments in the field of crypto market regulation: USA, EU, Mexico, France, China, OECD. Electronic resource]. Access mode - https://www2.deloitte.com/content/dam/Deloitte/ru/Documents/tax/lt-infocus/russian/2018/12-04.pdf (Date of access - 12.10.2019).

19. Coinmarketcap market capitalization. - [Electronic resource]. The access mode is https://coinmarketcap.com/ru/ (Date of access - 12.10.2019).

\section{МИРОВОЙ РЫНОК КРИПТОВАЛЮТ И СПЕЦИФИКА ЕГО РАЗВИТИЯ}

Ушаков Денис Сергеевич, доктор экономических наук, профессор, Университет Суан Сунанда Раджабат, (10300, Таиланд, г. Бангкок, 1У-Тхонг рд., Дусит), профессор кафедры международных экономических отношений, Южно-Российский институт управления - филиал Российской академии народного хозяйства и государственной службы при Президенте РФ (344002, Россия, г. Ростов-на-Дону, ул. Пушкинская, 70/54). Автор 33 публикаций в журналах и трудах конференций, индексируемых в Scopus (индекс Хирша в Scopus - 5). E-mail: fintaliano@yandex.ru

Подольская Татьяна Валентиновна, кандидат экономических наук, доцент, зав. кафедрой международных экономических отношений, Южно-Российский институт управления - филиал Российской академии народного хозяйства и государственной службы при Президенте РФ (344002, Россия, г. Ростов-наДону, ул. Пушкинская, 70/54). E-mail: podolskayat@uriu.ranepa.ru

томашевская Людмила Аврамовна, кандидат филологических наук, доцент кафедры иностранных языков и речевых коммуникаций, Южно-Российский институт управления - филиал Российской академии народного хозяйства и государственной службы при Президенте РФ (344002, Россия, г. Ростов-наДону, ул. Пушкинская, 70/54). E-mail: inyaz@ uriu.ranepa.ru

Сысоева Анна Андреевна, магистрант кафедры международных экономических отношений, ЮжноРоссийский институт управления - филиал Российской академии народного хозяйства и государственной службы при Президенте РФ (344002, Россия, г. Ростов-на-Дону, ул. Пушкинская, 70/54).

E-mail: anna_sysoeva94@mail.ru

\section{Аннотация}

В данной статье анализируется процесс появления и развития рынка криптовалют, дается обзор различных подходов к определению содержания понятия «криптовалюта». Авторами также представлен обзор основных участников рынка криптовалют, их функций и факторов, влияющих на современное развитие данной сферы.

Ключевые слова: криптовалюты, блокчейн, Биткойн, рынок криптовалют, электронные деньги, финансовые сделки, финансы, капитализация, финансовый рынок. 